\title{
PENGARUH KEPEMILIKAN INSTITUSIONAL TERHADAP KARAKTERISTIK PASAR SAHAM DI BURSA EFEK INDONESIA
}

\author{
Oleh: \\ Dr. Donalson Silalahi
}

\begin{abstract}
The role of institutional ownership in the financial markets became very important. However, until today there is no consensus among researchers about the influence of institutional ownership on the characteristic of stock market. Therefore, researchers are motivated to conduct further research the influence of institutional ownership on the characteristic of stock market.

The research conducted at the Indonesian Stock Exchange with traded spread and adverse selection costs as dependent variable and institutional ownership as independent variable. In addition to institutional ownership, also used standard deviation of common stock price and trading volume as a control variable to clarify the relationship of institutional ownership on the characteristic of stock market.

The study was conducted on 120 firms with observations in the period 2010-2011. All the required data obtained from the Indonesian Capital Market Directory. The results showed that: First, institutional ownership has a negative and significant effect on traded spread. Second, the variability of traded spread is able to be explained by the variability of institutional ownership, standard deviation of the stock price, and trading volume 24.8 percent. Third, institutional ownership has a negative and significant effect on adverse selection costs. Fourth, the variability of adverse selection costs is able to be explained by the variability of institutional ownership, standard deviation of the stock price, and trading volume 26.2 percent. Fifth, the relationship between institutional ownership to traded spread and adverse selection cost before and after entering the control variables remain negative and significant.
\end{abstract}

Keywords: institutional ownership, market characteristics, and stock exchange.

\section{PENDAHULUAN}

Dewasa ini, corporate governance semakin sering diperbincangkan disebabkan bangkrutnya beberapa perusahaan besar dan terjadinya krisis keuangan. Kondisi ini menggambarkan bahwa praktek corporate governance yang baik sangat penting dilaksanakan untuk meningkatkan kinerja perusahaan. Di samping praktek corporate governance yang baik, kinerja perusahaan juga dipengaruhi oleh perubahan kondisi ekonomi, kondisi industri, dan perilaku partisipan pasar.

Partisipan pasar, pada dasarnya terdiri dari investor piawai dan investor likuiditas. Kehadiran investor piawai dalam mekanisme perdagangan berdampak pada melebarnya bid-ask spread (Copeland dan Galai: 1983) sehingga pasar menjadi tidak likuid (Glosten dan Milgrom: 1985). Oleh karenanya, perlu di monitor kehadiran investor piawai dalam rangka meningkatkan likuiditas pasar. Selanjutnya, Bhide (1993) mengemukakan bahwa pemilik perusahaan berperan dalam menurunkan agency costs dengan memonitor manajer. Oleh karenanya, struktur kepemilikan perusahaan berperan dalam membuat keputusankeputusan penting suatu perusahaan.

Hingga dewasa ini belum ada suatu kesepakatan tentang seberapa besar komposisi kepemilikan perusahaan sehingga mereka dianggap berperan dalam membuat keputusan penting suatu perusahaan. Park (2009) mengemukakan bahwa jika porsi kepemilikan saham lebih besar dari 1 persen, maka posisi pemegang saham penting dalam perusahaan. Sebaliknya, jika porsi kepemilikan saham lebih rendah dari 1 persen, maka peranan mereka tidak begitu penting dalam perusahaan. Oleh karena itu, secara relatif hanya kepemilikan 
institusional yang dimungkinkan memiliki porsi kepemilikan saham lebih besar dari 1 persen.

Lebih lanjut, kepemilikan institusional telah menunjukkan perkembangan yang cukup pantastis. Pada tahun 1945, ekuitas perusahaan yang dimiliki oleh institusi sebesar 5 persen dan meningkat menjadi 24 persen pada tahun 1965. Selanjutnya, pada tahun 1981, kepemilikan institusi meningkat menjadi 38 persen, dan pada tahun 1993 sudah lebih dari 50 persen (Jennings et al.: 2002). Demikian juga halnya dengan kepemilikan saham di Indonesia, bahwa kepemilikan institusional telah mendominasi kepemilikan saham-saham perusahaan yang terdaftar di Bursa Efek Indonesia (ECFIN: 2011). Selanjutnya, hasil penelitian yang dilakukan oleh Dennis dan Weston (2001) menunjukkan bahwa investor institusi cenderung informed trading. Barabonev dan McNamara (2002) mengemukakan bahwa investor institusi sering dianggap sebagai investor yang memiliki informasi lebih lengkap tentang suatu perusahaan jika dibandingkan dengan investor individu.

Berdasarkan paparan tersebut, maka investor institusi atau kepemilikan institusional dapat dianggap sebagai investor yang informed dan mempengaruhi keputusan penting suatu perusahaan. Oleh karenanya, peranan kepemilikan institusional dalam memonitor perusahaan dan dampaknya terhadap karakteristik pasar semakin penting untuk diteliti.

Karakteristik pasar dimanifestasikan oleh berbagai aspek, di antaranya: order flow, price impact of trade, quoted depth dan quoted spread (Chen: 1999). Ketiga aspek tersebut pada dasarnya berkaitan dengan likuiditas pasar. Likuiditas pasar pada dasarnya dimanifestasikan oleh besaran spread dan spread pada dasarnya mengandung komponen order processing costs (Demsetz: 1968; Tinic :1972), inventory holding costs (Ho dan Stoll: 1981), dan adverse selection costs (Bagehot: 1971; Copeland dan Galai: 1983; Glosten dan Milgrom: 1985; Easley dan O'Hara : 1987).

Studi empiris yang dilakukan oleh Stoll (1989); Madhavan dan Smidt (1991) menunjukkan bahwa inventory holding costs relatif rendah sehingga order processing costs dan adverse selection costs merupakan determinan penting dari spread. Selanjutnya, hasil penelitian yang dilakukan oleh Silalahi (2012); Purba dan Silalahi (2012) menunjukkan bahwa informasi asimetris di Bursa Efek Indonesia relatif cukup besar. Artinya, adverse selection costs merupakan determinan penting dari spread. Oleh karenanya, karakteristik pasar dalam penelitian ini dimanifestasikan oleh variabel spread dan adverse selection costs.

Lebih lanjut, Chen (1999) menegaskan bahwa struktur kepemilikan perusahaan mempengaruhi karakteristik pasar dan karakteristik pasar juga berhubungan dengan variabel-variabel yang mempengaruhi struktur kepemilikan perusahaan. Oleh karena itu, dipergunakan variabel kontrol (standard deviasi harga saham dan volume perdagangan saham) untuk mengontrol hubungan kausal antara kepemilikan institusional dengan karakteristik pasar saham.

Berdasarkan paparan tersebut di atas, maka penelitian ini bertujuan untuk mendapatkan bukti empiris tentang pengaruh kepemilikan institusional terhadap karakteristik pasar saham (spread dan adverse selection costs) di Bursa Efek Indonesia dengan mempergunakan variabel standar deviasi harga dan volume perdagangan saham sebagai variabel kontrol.

\section{KERANGKA TEORITIS}

Corporate governance semakin sering diperbincangkan disebabkan bangkrutnya beberapa perusahaan besar, terjadinya krisis keuangan, dan perubahan pola kepemilikan perusahaan yang mengarah pada konsentrasi kepemilikan saham institusional (Syakhroza: 2005). Oleh karenanya, kepemilikan institusional berperan dalam memonitor dan akan mempengaruhi keputusan penting suatu perusahaan.

Jika kepemilikan institusional dapat mempengaruhi keputusan penting suatu perusahaan, maka bagaimana dampak dari kepemilikan institusional terhadap karakteristik 
pasar saham?. Berdasarkan review literatur, terdapat dua paradigma yang dapat dipergunakan untuk menjelaskan hubungan kausal antara kepemilikan institusional dengan karakteristik pasar, yaitu: paradigma adverse selection dan paradigma trading (Sarin et al. : 2000; Barabanov dan McNamara : 2002; Ginglinger dan Hamon : 2007).

Berdasarkan paradigma adverse selection, kepemilikan institusional atau investor institusi akan menghasilkan informasi asimetris di pasar modal. Investor institusi sering dipandang lebih informed daripada investor individu sehingga investor institusi menghasilkan informasi asimetris di pasar modal dan sebagai konsekuensinya akan menurunkan likuiditas. Artinya, kehadiran investor institusi atau kepemilikan institusional menurunkan likuiditas pasar. Paradigma ini selaras dengan hasil penelitian yang dilakukan oleh Kothane dan Laux (1995) dan Sarin et al. (2000) bahwa kepemilikan institusional memiliki hubungan yang positip dan signifikan dengan bid-ask spread.

Pada dasarnya, bid-ask spread mengandung komponen real friction dan information friction. Hasil penelitian yang dilakukan oleh Silalahi (2012); Purba dan Silalahi (2012) menunjukkan bahwa information friction di Bursa Efek Indonesia relatif cukup besar dan real friction relatif rendah. Oleh karenanya, adverse selection costs di Bursa Efek Indonesia merupakan komponen penting dari traded spread. Adverse selection costs muncul sebagai akibat terjadinya informasi asimetris di antara partisipan pasar. Oleh karenanya, kehadiran investor institusi akan meningkatkan informasi asimetris dalam mekanisme perdagangan, dan dengan demikian, diprediksi bahwa kepemilikan institusional berhubungan positip dengan adverse selection cost.

Dalam paradigma trading dikemukakan bahwa kepemilikan institusional akan meningkatkan likuiditas pasar melalui perbaikan penyebaran informasi di pasar modal. Artinya, kehadiran investor institusi mengakibatkan meningkatnya efisiensi informasi melalui persaingan sesama investor institusi. Paradigma ini selaras dengan hasil penelitian yang dilakukan oleh Chen (1999); Jennings et al. (2002); Barabanov dan McNamara (2002); Rubin (2007); dan Brockman et al. (2008) bahwa kepemilikan institusional memiliki hubungan yang negatip dan signifikan dengan bid-ask spread. Artinya, kepemilikan institusional dapat meningkatkan likuiditas pasar saham. Lebih lanjut, kehadiran investor institusi dimaksudkan untuk memperbaiki penyebaran informasi sehingga informasi asimetris dalam mekanisme perdagangan semakin rendah, dan dengan demikian diprediksi bahwa kepemilikan institusional berhubungan negatip dengan adverse selection costs.

Lebih lanjut, Chen (1999) menegaskan bahwa struktur kepemilikan perusahaan mempengaruhi karakteristik pasar saham dan karakteristik pasar saham juga berhubungan dengan variabel-variabel yang mempengaruhi struktur kepemilikan perusahaan. Oleh karena itu, dipergunakan variabel kontrol untuk mengontrol hubungan kausal antara kepemilikan institusional dengan karakteristik pasar. Variabel kontrol yang dipergunakan adalah standar deviasi harga dan volume perdagangan saham.

Standar deviasi harga saham menggabarkan tingkat risiko pasar. Tingkat risiko pasar dapat mempengaruhi besaran spread dengan dua cara. Pertama, risiko dapat mempengaruhi order flow dan dengan demikian akan mempengaruhi order processing costs. Kedua, risiko dapat mempengaruhi tingkat informasi asimetris dan dengan demikian akan mempengaruhi tingkat adverse selection costs. Oleh karena itu, standar deviasi harga saham berhubungan positip dengan spread dan adverse selection costs.

Selanjutnya, hubungan antara volume perdagangan saham dengan karakteristik pasar saham dijelaskan melalui paradigma persediaan dan informasi. Berdasarkan paradigma persediaan bahwa spread sudah sewajarnya ada sebagai kompensasi bagi perantara atas waktu dan modal yang telah diinvestasikan. Adanya spread memungkinkan perantara mampu menutupi biaya normal kegiatannya dan juga merupakan risiko bagi perantara akibat menyediakan jasa immediacy bagi investor. Dengan demikian, peningkatan volume perdagangan saham menggambarkan meningkatnya aktivitas perdagangan yang 
dilakukan oleh investor likuiditas dan juga merupakan signaling likuiditas pasar dengan harapan tidak terjadi penurunan likuiditas. Dengan mengacu pada paradigma persebut, maka volume perdagangan yang semakin besar akan meningkatkan likuiditas pasar saham. Artinya, volume perdagangan saham berhubungan negatip dengan spread dan adverse selection costs.

Selanjutnya, dalam paradigma informasi dikemukakan bahwa spread merupakan biaya yang berhubungan dengan kompensasi bagi perantara jika melakukan transaksi dengan investor piawai. Investor piawai melakukan aktivitas perdagangan dimotivasi oleh informasi private yang dimilikinya. Oleh karenanya, peningkatan volume perdagangan saham merupakan signal hadirnya investor piawai sehingga investor likuiditas mengalami kerugian bila melakukan transaksi dengan investor piawai. Kerugian tersebut dibebankan perantara kepada investor melalui pelebaran spread. Dengan mengacu pada paradigma tersebut, maka volume perdagangan saham yang semakin besar mengakibatkan likuiditas pasar saham semakin rendah. Artinya, volume perdagangan saham berhubungan positip dengan spread dan adverse selection costs.

Adverse selection costs merupakan komponen penting dari spread. Hingga dewasa ini telah banyak model yang dikembangkan untuk mengestimasi spread dan komponennya, di antaranya: Roll (1984); Stoll (1989) dan George et al. (1991). Dalam mengestimasi spread dipergunakan kovarians harga transaksi maupun harga kuotasi berdasarkan suatu asumsi bahwa pasar modal adalah efisien. Dengan demikian, model tersebut sangat sesuai untuk pasar modal yang sudah maju.

Pasar Modal Indonesia merupakan pasar modal yang sedang berkembang (Fuss: 2002). Dalam pasar modal yang sedang berkembang, pasar modal pada dasarnya belum efisien sehingga kovarians harga transaksi maupun harga kuotasi kurang sesuai bila diimplementasikan di pasar modal Indonesia. Model yang paling sesuai untuk dipergunakan dalam mengestimasi spread dan komponennya di pasar modal yang sedang berkembang adalah model indikator (Hanousek dan Podpiera: 2002).

Model indikator sebagaimana dikemukakan oleh Huang dan Stoll (1997); Stoll (2000) ditunjukkan pada persamaan berikut.

$$
\Delta \mathrm{P}_{\mathrm{t}}=\mathrm{S} / 2\left(\mathrm{Q}_{\mathrm{t}}-\mathrm{Q}_{\mathrm{t}-1}\right)+\lambda \mathrm{S} / 2 \mathrm{Q}_{\mathrm{t}-1}+\mathrm{e}_{\mathrm{t}}
$$

Berdasarkan pada persamaan (1) dapat dikemukakan bahwa $\Delta \mathrm{P}_{\mathrm{t}}$ merupakan perubahan harga transaksi saham pada periode $t, Q_{t}$ merupakan order flow pada periode $t, Q_{t-1}$ merupakan order flow pada periode $\mathrm{t}-1$, dan parameter $\mathrm{S} / 2$ menggambarkan traded spread serta parameter $\lambda$ menggambarkan jumlah komponen inventory holding costs dan adverse selection costs.

Selanjutnya, spread terdiri dari komponen order processing costs, inventory imbalance holding costs, dan adverse selection costs. Komponen order processing costs dan inventory imbalance holding cost disebut sebagai real friction dan adverse selection costs disebut sebagai information friction.

Untuk mengestimasi struktur spread atas komponen real friction dan information friction dipergunakan model yang dikemukakan oleh Glosten dan Harris (1988) sebagaimana ditunjukkan pada persamaan berikut:

$$
\Delta \mathrm{P}_{\mathrm{t}}=\mathrm{aS} / 2 \mathrm{Q}_{\mathrm{t}}+(1-\mathrm{a}) \mathrm{S} / 2 \Delta \mathrm{Q}_{\mathrm{t}}+\mathrm{e}_{\mathrm{t}}
$$

Berdasarkan pada persamaan (2) dapat dikemukakan bahwa $\Delta \mathrm{P}_{\mathrm{t}}$ merupakan perubahan harga transaksi saham pada periode $t, Q_{t}$ merupakan order flow pada periode $t, \Delta Q_{t}$ merupakan perubahan order flow pada periode $t$, parameter $a(S / 2)$ menggambarkan komponen information friction atau adverse selection costs dan parameter $\left(\begin{array}{lll}1 & -\mathrm{a}\end{array}\right) \mathrm{S} / 2$ menggambarkan komponen real friction.

\section{METODE PENELITIAN}


Variabel yang dipergunakan dalam penelitian ini terdiri dari: variabel dependen dan variabel independen. Variabel dependen adalah karakteristik pasar saham yang dimanifestasikan oleh besaran traded spread dan adverse selection costs. Traded spread menggambarkan likuiditas pasar saham perusahaan. Adverse selection costs menggambarkan biaya transaksi yang timbul akibat adanya informasi asimetris dalam mekanisme perdagangan.

Variabel independen adalah kepemilikan institusional. Kepemilikan institusional menggambarkan persentase kepemilikan saham oleh institusi. Kepemilikan institusional diukur dengan membandingkan jumlah saham yang dimiliki oleh semua institusi dengan jumlah saham yang terdaftar untuk masing-masing perusahaan.

Di samping kepemilikan institusional, variabel independen lainnya adalah standar deviasi harga dan volume perdagangan saham. Standar deviasi harga dan volume perdagangan saham merupakan variabel kontrol yang dipergunakan untuk memperjelas arah hubungan antara kepemilikan institusional dengan kharakteristik pasar. Standar deviasi harga saham menggambarkan tingkat risiko pasar dan volume perdagangan saham menggambarkan aktivitas perdagangan yang dilakukan oleh masing-masing investor.

Populasi dalam penelitian ini adalah semua perusahaan yang terdaftar di Bursa Efek Indonesia dengan periode pengamatan selama tahun 2010 - 2011. Jumlah perusahaan yang terdaftar di Bursa Efek Indonesia pada akhir tahun 2011 sebanyak 428 perusahaan dengan sample size sebanyak 120 perusahaan. Selanjutnya, untuk setiap perusahaan, aktivitas pasar yang diobservasi sebanyak 16 periode. Observasi ini dipergunakan untuk mengestimasi traded spread, adverse selection costs dan standar deviasi harga saham. Dengan demikian, teknik pengambilan sampel adalah purposive sampling (Indriantoro dan Supomo: 1999).

Data yang dipergunakan adalah data sekunder, yaitu: data harga saham penutupan, volume perdagangan saham, dan kepemilikan institusional masing-masing perusahaan. Data tersebut didapatkan dari Indonesian Capital Market Directory Tahun 2011. Oleh karenanya, teknik pengambilan data adalah teknik dokumentasi.

Dalam menjelaskan hubungan kausal antara kepemilikan institusional dengan karakteristik pasar dilakukan melalui 3 tahap. Tahap pertama, adalah mengestimasi traded spread dan adverse selection costs dengan mempergunakan persamaan 1 dan 2. Tahap kedua, adalah menghubungkan kepemilikan institusional dengan traded spread dan adverse selection costs dengan mempergunakan persamaan regressi berikut:

TS $=a_{0}+\beta_{1} K I+\varepsilon$

3)

$$
\mathrm{ASC}=\mathrm{a}_{0}+\beta_{1} \mathrm{KI}+
$$

4)

Tahap ketiga, adalah menghubungkan kepemilikan institusional dengan traded spread dan adverse selection costs serta memasukkan variabel kontrol dengan mempergunakan persamaan regressi berikut:

$\mathrm{TS}=\mathrm{a}_{0}+\beta_{1} \mathrm{KI}+\beta_{2} \mathrm{SDH}+\beta_{3} \mathrm{VP}+\varepsilon$

5)

$$
\mathrm{ASC}=\mathrm{a}_{0}+\beta_{1} \mathrm{KI}+\beta_{2} \mathrm{SDH}+\beta_{3} \mathrm{VP}+\varepsilon
$$

6)

dimana TS merupakan traded spread perusahaan i, ASC merupakan adverse selection costs perusahaan i, KI merupakan kepemilikan institusional perusahaan i, SDH merupakan standar deviasi harga saham perusahaan i, VP merupakan volume perdagangan saham perusahaan $i$, a merupakan konstanta, $\beta_{1}$ merupakan koefisien pengaruh kepemilikan 
institusional terhadap traded spread dan adverse selection costs, $\beta_{2}$ merupakan koefisien pengaruh standar deviasi harga saham terhadap traded spread dan adverse selection costs, dan $\beta_{3}$ merupakan koefisien pengaruh volume perdagangan saham terhadap traded spread dan adverse selection costs.

Untuk menjelaskan pengaruh masing-masing variabel kepemilikan institusional, standar deviasi harga saham, dan volume perdagangan saham terhadap traded spread dan adverse selection costs dipergunakan uji $\mathrm{t}$ dengan a sebesar 10 persen. Selanjutnya, untuk menjelaskan pengaruh secara serentak variabel kepemilikan institusional, standar deviasi harga saham, dan volume perdagangan saham terhadap traded spread dan adverse selection costs dipergunakan uji $\mathrm{F}$ dengan a sebesar 10 persen serta data diolah dengan mempergunakan program SPSS Version 18.

\section{HASIL DAN PEMBAHASAN}

\section{Kepemilikan Institusional, Standar Deviasi Harga, Volume Perdagangan, dan Karakteristik Pasar Saham}

Deskripsi data kepemilikan institusional, standar deviasi harga, volume perdagangan dan karakteristik pasar saham perusahaan-perusahaan yang menjadi sampel dalam penelitian ini dapat dilihat pada Tabel 1 berikut.

Tabel 1. Deskripsi Data Kepemilikan Institusional, Standar Deviasi Harga Saham Volume Perdagangan Saham, Traded Spread, dan Adverse Selection Costs

\begin{tabular}{|l|r|r|r|r|r|r|}
\hline \multirow{2}{*}{ Variabel } & \multicolumn{1}{|c|}{$\mathrm{N}$} & \multicolumn{1}{c|}{ Range } & Minimum & Maximum & \multicolumn{1}{c|}{ Mean } & \multicolumn{1}{c|}{$\begin{array}{c}\text { Standard } \\
\text { Deviation }\end{array}$} \\
\cline { 2 - 7 } & Statistic & \multicolumn{1}{c|}{ Statistic } & \multicolumn{1}{c|}{ Statistic } & \multicolumn{1}{c|}{ Statistic } & \multicolumn{1}{c|}{ Statistic } & \multicolumn{1}{c|}{ Statistic } \\
\hline Institusi & 120 & 78.06 & 21.03 & 99.09 & 70.91 & 19.02 \\
\hline Std.Dev & 120 & 3457.77 & .001 & $3.457,77$ & 169.3295 & 376.43626 \\
\hline Volume & 120 & 7957191.00 & .001 & 7957191.00 & 191.239 .0917 & $7.69490 \mathrm{E} 5$ \\
\hline Traded Spread & 120 & 1.732 & 0.001 & 1.733 & 1.005 & 0.331 \\
\hline $\begin{array}{l}\text { Adverse } \\
\text { Selection Costs }\end{array}$ & 120 & 1.321 & 0.001 & 1.322 & 0.709 & 0.260 \\
\hline
\end{tabular}

Sumber: Hasil Penelitian dan Sudah Diolah.

Berdasarkan Tabel 1 dapat dikemukakan bahwa total kepemilikan institusional berada dalam kisaran 21,03 - 99,09 persen dengan range sebesar 78,06 persen, rata-rata adalah 70,91 persen dan standar deviasi sebesar 19,02 persen. Kondisi ini menggambarkan bahwa saham-saham perusahaan yang diamati cenderung dimiliki oleh investor institusi. Standar deviasi harga saham berada dalam kisaran 0,001 - 3.457,77 dengan range sebesar 3457,77 dan rata-rata adalah 169.3295. Kondisi ini menggambarkan bahwa tingkat risiko ataupun volatilitas harga saham relatif tinggi. Selanjutnya, volume perdagangan saham berada dalam kisaran 0,001 - 7957191 dengan rata-rata sebesar 191.239.0917 dan standar deviasi sebesar 7.69490E5. Kondisi ini menggambarkan bahwa volume perdagangan saham cukup fluktuatif.

Karakteristik pasar saham yang dimanifestasikan oleh variabel traded spread berada dalam kisaran 0,001 - 1,730 dengan rata-rata adalah 1,005 dan standar deviasi adalah 0,331. Karakteristik pasar saham berikutnya adalah adverse selection costs berada dalam kisaran 0,001 - 0,132 dengan rata-rata 0,709 dan standar deviasi adalah 0,260. Kondisi ini menggambarkan bahwa karakteristik pasar saham perusahaan yang dimanifestasikan oleh traded spread dan adverse selection costs cukup fluktuatif. 


\section{Pengaruh Kepemilikan Institusional Terhadap Karakteristik Pasar Saham Sebelum dan Sesudah Memasukkan Variabel Kontrol}

Rekapitulasi hasil perhitungan pengaruh kepemilikan institusional terhadap karakteristik pasar saham (traded spread) sebelum memasukkan variabel kontrol dapat dilihat pada Tabel 2 berikut ini.

Tabel 2. Rekapitulasi Hasil Penelitian Pengaruh Kepemilikan Institusional Terhadap Traded Spread

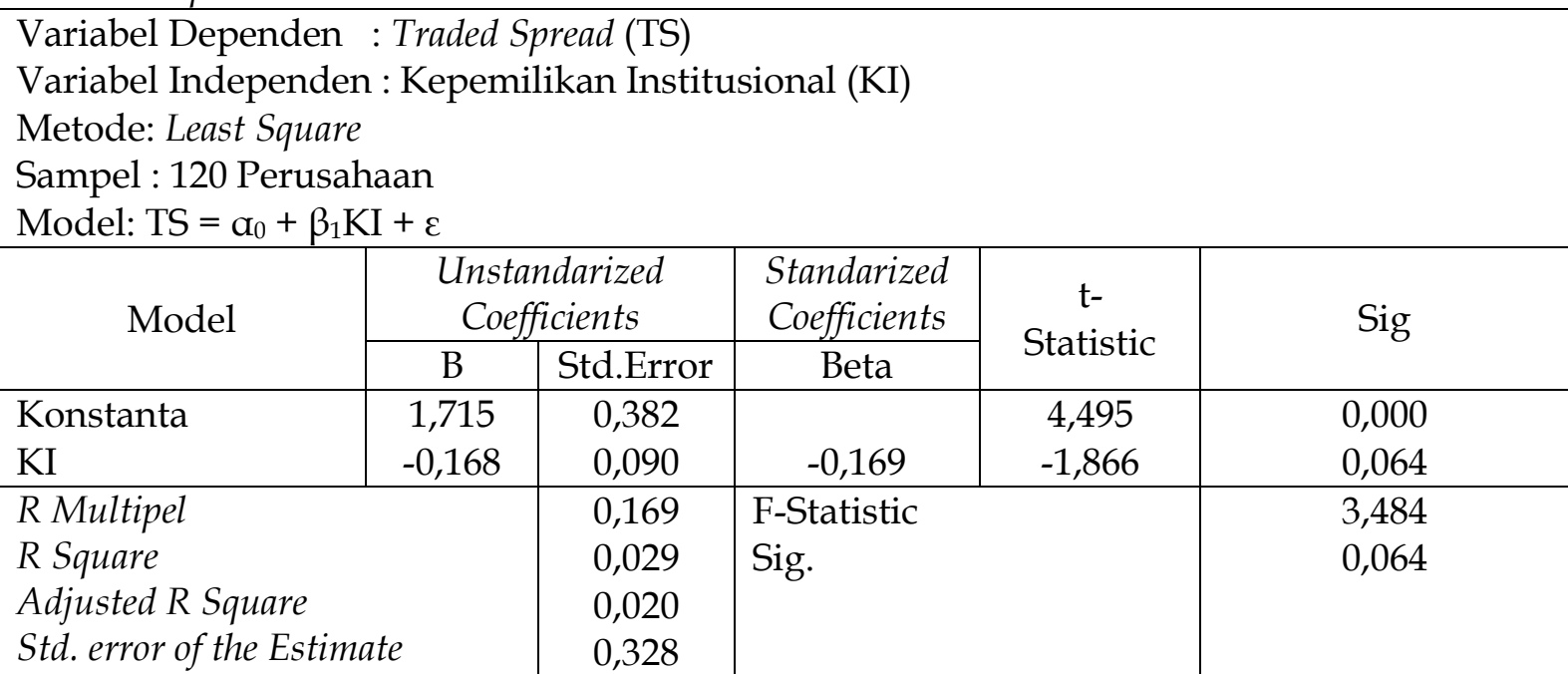

Sumber: Hasil Olahan Data Penelitian dengan Mempergunakan Program SPSS Version 18.

Berdasarkan Tabel 2, dapat dikemukakan bahwa nilai koefisien determinan sebesar 2,9 persen dengan nilai F-statistik adalah 3,484 dan probabilitas sebesar 0,064. Selanjutnya, nilai koefisien regressi variabel kepemilikan institusional sebesar - 0,169 dengan nilai tsatistik adalah $-1,866$ dan probabilitas sebesar 0,064. Dengan demikian kepemilikan institusional berpengaruh negatip dan signifikan terhadap traded spread.

Rekapitulasi perhitungan pengaruh kepemilikan institusional terhadap traded spread dengan memasukkan variabel kontrol ditunjukkan pada Tabel 3 berikut.

Tabel 3. Rekapitulasi Hasil Penelitian Pengaruh Kepemilikan Institusional, Standar Deviasi Harga Saham, dan Volume Perdagangan Saham Terhadap Traded Spread

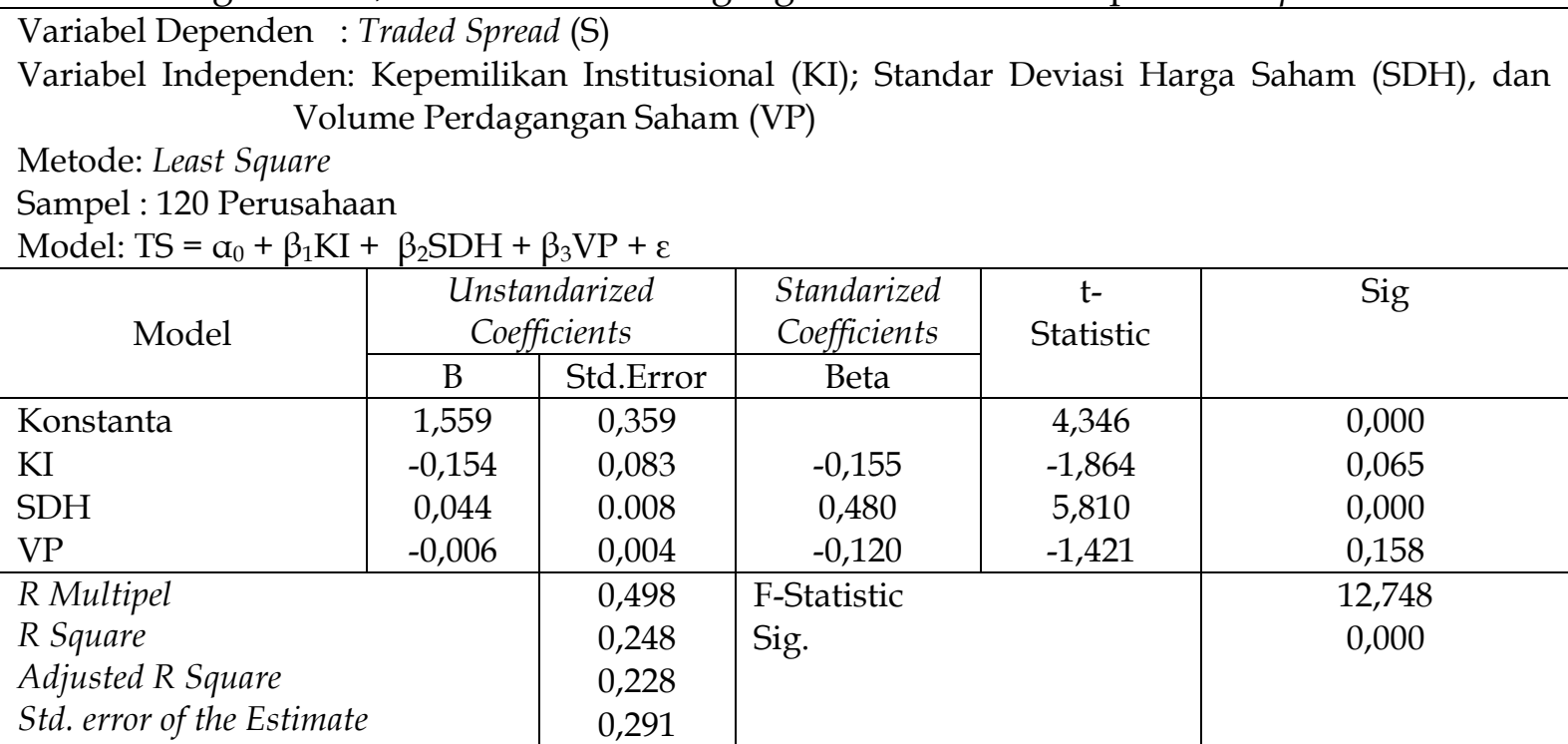

Sumber: Hasil Olahan Data Penelitian dengan Mempergunakan Program SPSS Version 18.

Berdasarkan Tabel 3, dapat dikemukakan bahwa nilai koefisien determinan sebesar 24,8 persen dengan nilai F-statistik adalah 12,748 dan probabilitas sebesar 0,000 . Selanjutnya, 
nilai koefisien regressi variabel kepemilikan institusional sebesar - 0,155 dengan nilai $t$ statistik adalah $-1,864$ dan probabilitas sebesar 0,065. Nilai koefisien regressi variabel standar deviasi harga saham sebesar 0,480 dengan nilai t-statistik adalah 5,810 dan probabilitas sebesar 0,000 . Nilai koefisien regressi variabel volume perdagangan saham sebesa - 0,120 dengan nilai t-statistik adalah -1,421 dan probabilitas sebesar 0,158.

Dengan demikian, kepemilikan institusional berpengaruh negatip dan signifikan terhadap traded spread, standar deviasi harga saham berpengaruh positip dan signifikan terhadap traded spread, dan volume perdagangan berpengaruh negatip dan tidak signifikan terhadap traded spread. Akan tetapi, dengan mengacu pendapat dari Cohen et al. (1987) bahwa jika nilai t-statistic sebesar 2 - 3 dikemukakan sebagai quite significant, nilai t-satistic sebesar 1 - 2 dikemukakan sebagai moderately significant dan nilai t-statistic $<1$ disebut tidak signikan, maka volume perdagangan saham berpengaruh negatip dan signifikan terhadap traded spread (moderat).

Hasil penelitian tersebut di atas menunjukkan bahwa koefisien arah pengaruh kepemilikan institusional terhadap traded spread baik sebelum maupun sesudah dimasukkan variabel kontrol adalah sama. Oleh karena itu, kehadiran investor institusi atau kepemilikan institusional di Bursa Efek Indonesia berperan dalam meningkatkan likuiditas pasar saham. Investor institusi atau kepemilikan institusional menyebarkan informasi dalam pembentukan harga saham, serta melakukan pengawasan secara efektif dan efisien terhadap manajemen dan berperan dalam membuat keputusan-keputusan penting suatu perusahaan sehingga likuiditas pasar saham semakin baik. Dengan demikian, hasil penelitian ini selaras dengan hasil penelitian yang dilakukan oleh Chen (1999); Jennings et al. (2002); Rubin (2007); dan Brockman et al. (2008) dan mendukung paradigma trading.

Rekapitulasi hasil perhitungan pengaruh kepemilikan institusional terhadap karakteristik pasar saham (adverse selection costs) sebelum memasukkan variabel kontrol dapat dilihat pada Tabel 4 berikut ini.

Tabel 4. Rekapitulasi Hasil Penelitian Pengaruh Kepemilikan Institusional Terhadap Adverse Selection Costs

\begin{tabular}{|c|c|c|c|c|c|}
\hline \multicolumn{6}{|c|}{$\begin{array}{l}\text { Variabel Dependen : Adverse Selection Costs (AS) } \\
\text { Variabel Independen : Kepemilikan Institusi (KI) } \\
\text { Metode: Least Square } \\
\text { Sampel : } 120 \text { Perusahaan } \\
\text { Model: AS }=\alpha_{0}+\beta_{1} \mathrm{KI}+\varepsilon\end{array}$} \\
\hline \multirow[t]{2}{*}{ Model } & \multicolumn{2}{|c|}{$\begin{array}{c}\text { Unstandarized } \\
\text { Coefficients }\end{array}$} & $\begin{array}{l}\text { Standarized } \\
\text { Coefficients }\end{array}$ & \multirow[t]{2}{*}{$\begin{array}{c}\mathrm{t}- \\
\text { Statistic }\end{array}$} & \multirow[t]{2}{*}{ Sig } \\
\hline & B & Std.Error & Beta & & \\
\hline $\begin{array}{l}\text { Konstanta } \\
\text { KI }\end{array}$ & $\begin{array}{r}1,324 \\
-0,146\end{array}$ & $\begin{array}{l}0,299 \\
0,071\end{array}$ & $-0,186$ & $\begin{array}{r}4,429 \\
-2,062\end{array}$ & $\begin{array}{l}0,000 \\
0,041\end{array}$ \\
\hline $\begin{array}{l}R \text { Multipel } \\
R \text { Square } \\
\text { Adjusted } R \text { Squ } \\
\text { Std. error of the }\end{array}$ & & $\begin{array}{l}0,186 \\
0,035 \\
0,027 \\
0,257\end{array}$ & \multicolumn{2}{|l|}{$\begin{array}{l}\text { F-Statistic } \\
\text { Sig. }\end{array}$} & $\begin{array}{l}4,250 \\
0,041\end{array}$ \\
\hline
\end{tabular}

Sumber: Hasil Olahan Data Penelitian dengan Mempergunakan Program SPSS Version 18.

Berdasarkan Tabel 4 tersebut di atas, dapat dikemukakan bahwa nilai koefisien determinan sebesar 3,5 persen dengan nilai F-statistik adalah 4,250 dan probabilitas sebesar 0,041 . Selanjutnya, nilai koefisien regressi variabel kepemilikan institusional sebesar - 0,186 dengan nilai t-satistik adalah -2,062 dan probabilitas sebesar 0,041. Dengan demikian, kepemilikan institusional berpengaruh negatip dan signifikan terhadap adverse selection costs.

Untuk memperjelas arah hubungan kausal antara kepemilikan institusional dengan adverse selection costs dipergunakan variabel kontrol. Rekapitulasi perhitungan pengaruh 
kepemilikan institusional terhadap adverse selection costs dengan memasukkan variabel kontrol ditunjukkan pada Tabel 5 berikut.

Tabel 5. Rekapitulasi Hasil Penelitian Pengaruh Kepemilikan Institusional, Standar Deviasi Harga Saham, dan Volume Perdagangan Saham Terhadap Adverse Selection Costs

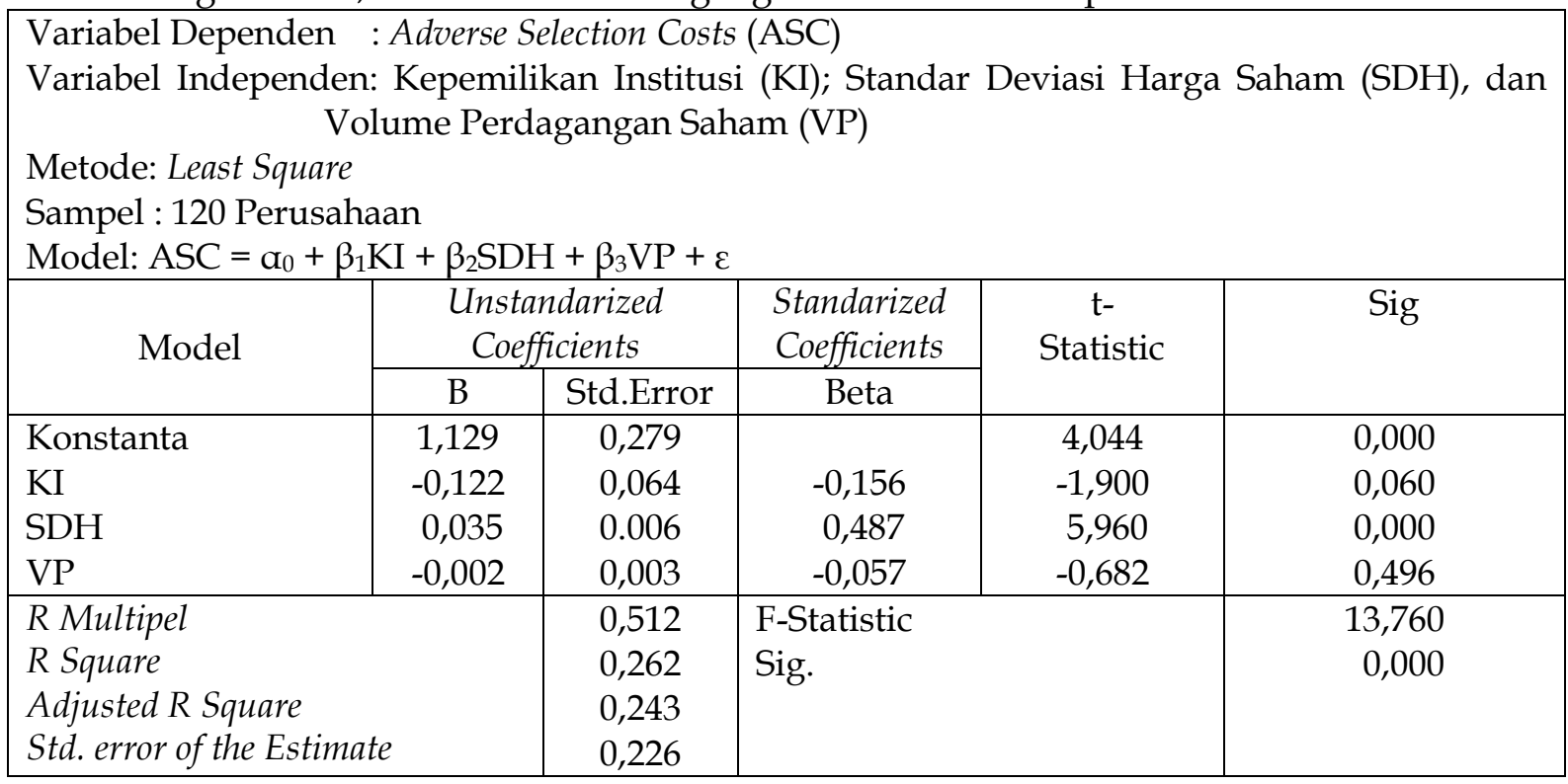

Sumber: Hasil Olahan Data Penelitian dengan Mempergunakan Program SPSS Version 18.

Berdasarkan Tabel 5 tersebut di atas, dapat dikemukakan bahwa nilai koefisien determinan sebesar 26,2 persen dengan nilai F-statistik adalah 13,760 dan probabilitas sebesar 0,000 . Selanjutnya, nilai koefisien regressi variabel kepemilikan institusional sebesar $-0,156$ dengan nilai t-satistik adalah $-1,900$ dan probabilitas sebesar 0,060 . Nilai koefisien regressi variabel standar deviasi harga saham sebesar 0,487 dengan nilai t-statistik adalah 5,960 dan probabilitas sebesar 0,000 . Nilai koefisien regressi variabel volume perdagangan saham sebesar -0,057 dengan nilai t-statistik adalah -0,682 dan probabilitas sebesar 0,496. Dengan demikian, kepemilikan institusional berpengaruh negatip dan signifikan terhadap adverse selection costs. Selanjutnya, standar deviasi harga saham berpengaruh positip dan signifikan terhadap adverse selection costs serta volume perdagangan saham berpengaruh negatip dan tidak signifikan terhadap adverse selection costs.

Berdasarkan hasil penelitian tersebut dapat dikemukakan bahwa kehadiran investor institusi atau kepemilikan institusional dapat menurunkan adverse selection costs. Penelitian ini sesuai dengan hasil penelitian yang dilakukan oleh Jennings et al. (2002) serta selaras dengan paradigma trading. Artinya, kehadiran investor institusi atau kepemilikan institusional berperan dalam penyebaran informasi sehingga informasi asimetris dalam mekanisme perdagangan semakin rendah, artinya adverse selection costs semakin rendah.

Kepemilikan institusional yang semakin besar menggabarkan meningkatnya peranan mereka dalam mempengaruhi pengambilan keputusan penting perusahaan. Artinya, investor institusi termotivasi untuk memperbaiki investasi-investasi yang dilakukan manajemen perusahaan melalui pengawasan yang efektif dan efisien. Dengan demikian, kehadiran kepemilikan institusional di Bursa Efek Indonesia sangat penting sebab dapat memperbaiki karakteristik pasar saham melalui penurunan traded spread dan adverse selection costs dalam mekanisme perdagangan. 


\section{Kesimpulan}

\section{KESIMPULAN DAN SARAN}

Berdasarkan hasil penelitian dan pembahasan dapat dikemukakan kesimpulan sebagai berikut:

Pertama, pengaruh kepemilikan institusional terhadap traded spread dan adverse selection costs sebelum dan sesudah memasukkan variabel kontrol (standar deviasi harga saham dan volume perdagangan saham) adalah negatip dan signifikan.

Kedua, variabilitas variabel traded spread mampu dijelaskan oleh variabilitas variabel kepemilikan institusional, standar deviasi harga saham dan volume perdagangan saham sebesar 24,8 persen dengan nilai F-statistik sebesar 12,748 dan probabilitas adalah 0,000.

Ketiga, variabilitas variabel adverse selection costs mampu dijelaskan oleh variabilitas variabel kepemilikan institusional, standar deviasi harga saham dan volume perdagangan saham sebesar 26,2 persen dengan nilai F-statistik sebesar 13,760 dan probabilitas adalah 0,000 .

\section{Saran}

Mengacu pada kesimpulan tersebut, maka dikemukakan saran sebagai berikut:

Pertama, kepemilikan institusional dapat memperbaiki tingkat likuiditas pasar saham melalui penurunan traded spread dan adverse selection costs dalam mekanisme perdagangan. Oleh karenanya, jika investor mensyaratkan imbal hasil yang lebih besar atas sekuritas yang tidak likuid, maka perusahaan-perusahaan yang go public dapat mentargetkan partisipan pasar, yaitu investor institusi sebab investor tersebut dapat memperbaiki tingkat likuiditas pasar saham.

Kedua, hasil penelitian ini dapat dipergunakan sebagai dasar bagi regulator dalam membuat regulasi untuk meningkatkan kualitas pasar saham dan dalam menentukan corporate governance korporasi. optimal.

Ketiga, diperlukan penelitian lanjutan tentang kepemilikan institusional yang

\section{DAFTAR PUSTAKA}

Agarwal, P., 2008. Institutional Ownership and Stock Liquidity, Working Paper Cornell University - Johnson Graduate School of Management.

Bagehot, W., 1971. The Only Game in Town, Financial Analysts Journal 22, 12 - 14.

Barabanov, Sergey S, and Michael J. McNamara, 2002. Market Perception of Information Asymmetry: Concentration of Ownership by Different Type of Institutions and BidAsk Spread, Working Paper, University of St. Thomas.

Bhide, A., 1993. The Hidden Costs of Stock Market Liquidity, Journal of Financial Economics 34, 31-51.

Brockman, Paul, Dennis Y. Chung, and Xuemin S. Yan, 2008. Block Ownership, Trading Activity, and Market Liquidity, Journal of Financial and Quantitative Analysis, Forthcoming.

Chen, Honghui, 1999. Two Essays on Ownership and Market Characteristics, Disertation, Virgina Polytechnic Institute and state University.

Chiang, R. and P. C. Venkatesh, 1988. Insider Holdings and Perceptions of Information Asymmetry: A Note, Journal of Finance 43, 1041-1048.

Cohen, Jerome B.; Arthur Zeikel; and Edward D. Zinbarg, 1987. Investment Analysis and Portfolio Management, Fifth Edition, Richard D. Irwin, Inc. 
Copeland, Thomas E., and Dan Galai, 1983. Information Effects on the Bid-Ask Spread, Journal of Finance 38, 1457-1469.

Demsetz, H, 1968. The Cost of Transaction, Quarterly Journal of Economics 82, 33 - 53.

Dennis, Patrick J., and James P. Weston, 2001. Who's Informed? An Analysis of Stock Ownership and Informed Trading, Working Paper, University of Virginia.

Easley, David, and Maureen O'Hara, 1987. Price, Trade Size, and Information in Securities Markets, Journal of Financial Economics 19, 69-90.

Fabozzi, F., 1979. Bid-Ask Spreads for Over-the-Counter Stocks, Journal of Economics and Business 32, 56-65.

Fuss, Roland, 2002. The Financial Characteristics between Emerging and Developed Equity Markets, Working Paper, Department of Empirical Economic Research and Econometrics, Albert-Ludwigs-University Freiburg.

George, T., G. Kaul and M. Nimalendran, 1991. Estimation of the Bid-Ask Spread and its Components: A New Approach, Review of Financial Studies 4, 623-656.

Ginglinger, Edith, and Jacques Hamon, 2007. Ownership, Control and Market Liquidity, Finance International Meeting AFFI-EUROFIDAI Paper.

Glosten, L. , and P. Milgrom, 1985. Bid Ask and Transaction Prices in a Specialist Market with Heterogeneously Informed Traders, Journal of Financial Economics 13, 71-100.

Glosten, L. R. and L. E. Harris, 1988. Estimating the Components of the Bid-Ask Spread, Journal of Financial Economics 21, 123-142.

Hanousek, Jan and Richard Podpiera, 2002. Informed Trading and Bid-Ask Spread: Evidence from an Emerging Market, Working Paper, CERGE-EI, Czech Republic.

Huang, R., dan H. Stoll, 1997. The Component of the Bid-Ask Spread: A General Approach, Review of Financial Studies 10, 995 - 1034.

Indriantoro, Nur dan Bambang Supomo, 1999. Metodologi Penelitian Bisnis untuk Akuntansi dan Manajemen, Edisi Pertama, BPFE, Yogyakarta.

Institute for Economic and Financial Research, 2011. Indonesian Capital Market Directory, Jakarta.

Jennings, William W; Karen Schnatterly; and Paul J. Seguim, 2002, Institutional Ownership, Information and Liquidity, Innovation in Investment and Corporate Finance 7, 41 - 71.

Kothare, M. and P. Laux, 1995. Trading Costs and the Trading Systems for Nasdaq Stocks, Financial Analyst Journal 51, 42-53.

Madhavan, A. and S. Smidt, 1991. A Bayesian Model of Intra Day Specialist Pricing, Journal of Financial Economics 30, 99-134.

Munthe, Kornel, 2012. Pengaruh Struktur Kepemilikan Perusahaan terhadap Kinerja Perusahaan pada Perusahaan yang telah Tercatat di Bursa Efek Indonesia, Jurnal Manajemen 1, 218 - 227.

Permanasari, Wien Ika, 2010. Pengaruh Kepemilikan Manajemen, Kepemilikan Institusional, dan Corporate Social Responsibility terhadap Nilai Perusahaan, Skripsi, Universitas Diponegoro, Semarang.

Purba, Saut dan Donalson Silalahi, 2012. Analisis Dampak Information Friction dan Real Friction terhadap Stock Return di Bursa Efek Indonesia, Jurnal Manajemen 1, 228 - 241 
Roll, Richard, 1984. A Simple Implicit Measure of the Effective Bid-Ask Spread in an Efficient Market, Journal of Finance 1127-1139.

Sarin, A., Shastri, K. A. \& Shastri, K. 2000. Ownership Structure and Market Liquidity. Working Paper, Santa Clara University.

Silalahi, Donalson, 2012. Pengaruh Volume Perdagangan Saham Terhadap Information Dan Non-Information Cost Di Bursa Efek Indonesia, Media Unika 25, 178 - 188.

Stoll, Hans R., 1989. Inferring the Components of the Bid-Ask Spread: Theory and Empirical Tests, Jounal of finance 44, 115 - 134.

Stoll, Hans R., 2000, Friction, Journal of Finance 55, 1479-1514.

Sukamuja, Sukmawati. 2004. Good Corporate Governance di Sektor Keuangan: Dampak GCG Terhadap Kinerja Perusahaan (Kasus di Bursa Efek Jakarta). BENEFIT 8, 1 - 25.

Syakhroza, H. Akhmad, 2005. Corporate Governance: Sejarah dan Perkembangannya, Teori, Model, dan Sitem Governance serta Aplikasinya pada Perusahaan BUMN, Fakultas Ekonomi Universitas Indonesia, Jakarta.

Tinic, S. M., 1972. The Economics of Liquidity Services, The Quarterly Journal of Economics 86, 79-93. 